\title{
Kegiatan Budaya Sebagai Alat Interaksi dan Komunikasi Dalam Pendidikan
}

\author{
Dewi Kartika \\ Institut Agama Islam Negeri (IAIN) Curup \\ dkartika@gmail.com
}

\begin{abstract}
This paper talks about culture which has a role as a communication tool in education. The aim to be achieved in this study is that culture is an element that has influence in the process of education, and has a role as a tool to interact in education. Culture and education are two things that are interconnected. Because in education there is a cultural transmission. To understand the value of cultural activities as an educational tool, we must clarify understanding of basic concepts such as: Creativity is a process in which an individual, as a result of his personal abilities and opportunities and in his interactions with his environment, will look for new and / or original products that are adequate for the situation in question this product can be concrete or abstract. Interaction and communication, Interaction is reciprocal attention between two people (or more) to one another or to an object or third person. Partners in this interaction focus their attention on the same goal (one another or third person or a certain object). This mutual attention is often responded to by gestures, speeches or actions. Whereas Communication means first of all sharing. We share and exchange interests, feelings, thoughts, opinions or information with a series of media codes, which are formed as signals and symbols, which can be understood and used by all communication partners.
\end{abstract}

Keywords: culture, interaction, communication, education

\begin{abstract}
Abstrak
Tulisan ini berbicara tentang kebudayaan yang memiliki peran sebagai alat komunikasi dalam pendidikan. Tujuan yang ingin dicapai dalam kajian ini adalah bahwa kebudayaan merupakan unsur yang memiliki pengaruh dalam proses pendidikan, dan memiliki peran sebagai alat untuk berinteraksi dalam pendidikan. Budaya dan pendidikan merupakan dua hal yang saling berhubungan. Karena dalam pendidikan terjadinya transmisi budaya. Untuk memahami
\end{abstract}


nilai kegiatan budaya sebagai alat pendidikan, kita harus memperjelas pemahaman konsep-konsep dasar seperti: Kreatifitas adalah proses di mana seorang individu, sebagai hasil dari kemampuan dan kesempatan pribadinya serta dalam interaksinya dengan lingkungannya, akan mencari produk baru dan/atau original yang memadai untuk situasi yang bersangkutan produk ini dapat bersifat konkret ataupun abstrak. Interaksi dan komunikasi, Interaksi adalah perhatian timbal balik antara dua orang (atau lebih) terhadap satu dengan lainnya atau terhadap suatu obyek atau orang ketiga. Mitra-mitra dalam interaksi ini memfokuskan perhatiannya pada sasaran yang sama (satu sama lainnya atau orang ketiga atau suatu obyek tertentu). Perhatian timbal balik ini sering kali direspon dengan isyarat, ujaran atau tindakan. Sedangkan Komunikasi artinya pertama-tama adalah berbagi. Kita berbagi dan saling bertukar minat, perasaan, pikiran, pendapat atau informasi dengan media rangkaian kode-kode, yang terbentuk sebagai simyal dan simbol-simbol, yang dapat dimengerti dan dipergunakan oleh semua mitra komunikasi itu.

Kata Kunci: budaya, interaksi, komunikasi, pendidikan

\section{Pendahuluan}

Dalam tulisan ini penekanan khusus akan diberikan pada potensi kegiatan budaya sebagai alat penting dalam pendidikan serta alat untuk menjamin kualitas hidup yang lebih baik bagi anak dan orang dewasa dalam masyarakat secara keseluruhan. Secara khusus saya akan memfokuskan pada pentingnya kegiatan budaya untuk meningkatkan interaksi dan komunikasi dan karenanya juga meningkatkan pertumbuhan sosial dan emosional di dalam seting pendidikan inklusif yang formal maupun nonformal serta seting lainnya yang relevan. Seting inklusif mencakup semua anggota masyarakat tanpa memandang usia, fungsi indera, fisik atau kognitif, latar belakang budaya dan pengalaman. Dengan kata lain, kita membicarakan tentang keragaman alami dalam suatu masyarakat.

Konsep kegiatan budaya hanya meliputi kegiatan yang berkaitan dengan tari, musik, drama, seni rupa dan kerajinan (termasuk seni lukis dan seni pahat) dan bercerita. Kegiatan ini mencakup sejumlah besar pengalaman, termasuk warisan budaya yang relevan pada satu sisi, dan eksperimentasi dan kreasi anak dan orang dewasa sendiri sebagai hasil dari kreativitasnya sendiri pada sisi lain. Warisan budaya meliputi reproduksi lagu, tarian, cerita, pola grafik tradisional dll. Ini juga mencakup gaya atau cara bernyanyi, menari dll, yang telah diturunkan dari generasi ke generasi. Kegiatan budaya, di samping warisan budaya, meliputi improvisasi lelucon yang diciptakan secara spontan serta produksi baru yang lambat laun menjadi terstruktur sehingga akan dengan 
mudah diulang dan diwariskan kepada orang lain. Kita juga akan menemukan banyak contoh di mana improvisasi dan unsur-unsur yang sudah terstruktur dikombinasikan. Music jazz merupakan contoh yang baik untuk ini. Kegiatan budaya berimplikasi aktivitas dan partisipasi di satu pihak, dan partisipasi aktif sebagai pemirsa, penonton dan pendengar di pihak lain. Keduanya memberikan pengayaan kepada pesertanya.

\section{Pembahasan}

Untuk memahami nilai kegiatan budaya sebagai alat pendidikan, kita harus memperjelas pemahaman konsep-konsep dasar seperti:

- Pandangan dan pendekatan holistik

- Kreativitas

- Interaksi dan komunikasi.

\section{Pandangan dan pendekatan holistic}

Rehabilitasi dan terapi serta pendidikan mempunyai aspek-aspek yang berkaitan, yang kesemuanya saling terkait dan saling mempengaruhi (lihat ilustrasi no. 1).

Rehabilitasi - memulihkan, mengkompensasi atau mengembalikan fungsi-fungsi yang pernah hilang - akan mempunyai dampak terapeutik dan mempermudah belajar. Terapi yang baik dapat mempermudah belajar dan rehabilitasi, dan pendidikan yang baik mempunyai konsekuensi terapeutik dan dapat menjadi alat untuk rehabilitasi.

\section{Illustrasi 1: Kaitan antara pendidikan, rehabilitasi dan terapi}

Sebagaimana telah disebutkan di atas, meskipun ada kaitan antara rehabilitasi, terapi dan pendidikan, terdapat pula perbedaan mendasar di antara ketiga bidang ini secara umum, dan khususnya dalam kaitannya dengan kegiatan budaya. Terapi, dalam konteks ini psikoterapi, adalah yang paling menarik di antara ketiganya karena menyentuh bagian terdalam dari perasaan dan keadaan psikologis kita. Oleh karena itu para ahli terapi yang menggunakan kegiatan budaya membutuhkan pelatihan yang sangat baik dalam psikoterapi dan kegiatan budaya yang diterapkannya. Bidang ini tidak akan dibahas lebih Rehabilitasi Pendidikan Terapi. Saya hanya ingin menyebutkan terapi musik, terapi tari, psikodrama dan terapi seni sebagai jenis terapi yang paling mantap yang menggunakan kegiatan budaya. Sebagaimana disebutkan di atas, batas antara rehabilitasi, terapi dan pendidikan itu jelas. Pentingnya kegiatan budaya di dalam pendidikan bahkan lebih besar dibanding dalam rehabilitasi dan terapi. Dalam 
konteks ini kata pendidikan mencakup pendidikan, pendidikan kebutuhan khusus dan pendidikan inklusif. dua:

Ada beberapa tugas-tugas kegiatan budaya dalam pendidikan menjadi

1. Kegiatan budaya untuk kepentingannya sendiri yang Menyampaikan pengetahuan dan keterampilan dalam bidang seni rupa

2. Kegiatan budaya sebagai suatu alat dalam pendidikan

Pelajaran tentang berbagai kegiatan budaya sering kali merupakan satu mata pelajaran tersendiri, satu mata pelajaran yang juga disebut "kesenian", yang mencakup mata pelajaran seperti musik, tari, seni rupa (grafika dan seni pahat), drama, dll.

Ada sekolah yang memberikan pengajaran dalam seni pentas yang meliputi pengembangan keterampilan pentas dan belajar membuat komposisi, koreografi, melukis, dll. Mata pelajaran tersebut kadang-kadang merupakan bagian dari kurikulum regular dan/atau bagian dari kegiatan ekstra kurikuler.

Kadang-kadang kesenian dikaitkan dengan peristiwa sejarah, tradisi budaya daerah (lihat juga Kegiatan Budaya sebagai warisan budaya), geografi, dll. Dengan demikian anak akan memperoleh pengetahuan dan/atau keterampilan yang akan memberikan kepuasan serta dipersiapkan untuk kegiatan waktu luang bila sudah dewasa atau bahkan diarahkan untuk memperoleh pekerjaan dalam bidang ini. Akan tetapi, ada anak yang tidak menunjukkan motivasi untuk terlibat dalam kegiatan ini, mereka lebih menyukai hiking, bermain bola, membaca atau kegiatan-kegiatan lainnya. Bila bekerja dengan anak, kita bekerja dengan orang yang mempunyai pengalaman "masa lalu" atau "sejarah". Pengalaman ini bersifat intelektual, sosial, emosional, fisik dan intelektual. Anak memperoleh pengalaman sebagian karena proses perkembangan alami dan rasa ingin tahu dan inisiatif yang tiada habisnya. Namun, anak juga mendapatkan pengalaman berkat lingkungannya. Pengalaman-pengalaman ini juga terkait dengan interaksi, komunikasi dan bahasa.

Mengasuh dan mendidik anak memberi orang tua dan guru hak istimewa untuk memberi anak kesempatan untuk memperoleh pengalaman baru, mempersiapkan kondisi yang akan memberikannya kebebasan untuk mencari pengalamannya sendiri, serta mempersiapkannya untuk mendapatkan pengalaman baru di masa depan. Ini menuntut kita mempertimbangkan semua aspek perkembangan, baik aspek di dalam diri anak maupun aspek lingkungan. Ini mengharuskan kita melihat perkembangan anak dengan pendekatan ekologi atau holistik.

Ilustrasi pada halaman berikut menunjukkan bahwa fungsi fisik, social, emosional, dan intelektual anak saling mempengaruhi dalam perkembangannya. 
Lingkungan fisik dan sosial pada saat yang bersamaan akan juga mempengaruhi perkembangannya.

\section{Lingkungan dekat}

Bervariasi menurut tahap kehidupan seseorang. Lingkungan dekat tersebut mungkin adalah keluarga bagi anak bungsu, keluarga dan taman kanakkanak bagi anak usia prasekolah, keluarga dan sekolah dan akhirnya keluarga dan tempat kerja. Dengan kata lain, lingkungan dekat itu adalah lingkungan di mana seseorang merupakan bagiannya dalam kehidupannya setiap hari (atau hampir setiap hari). Anak atau orang dewasa akan mempunyai pengaruh langsung ataupun tidak langsung terhadap lingkungan dekatnya jika lingkungan itu "sehat". Kadar pengaruh ini bervariasi menurut dinamika komunikasi, kebiasaan dan tradisi seperti tingkat penghargaan yang diberikan kepada anak, pandangan yang dianut seseorang terhadap hak anak, demokrasi dan hubungan sosial di tempat kerja, dll.

\section{Lingkungan jauh}

Komunitas dan masyarakat umum - mencakup dinamika komunikasi, kebiasaan dan tradisi, hukum dan berbagai peraturan serta dampak media massa (koran, radio dan televisi). Di sini anak atau orang dewasa hanya mempunyai pengaruh tak langsung kecuali apabila dinamika demokrasi berjalan baik. Pengaruh tak langsung, antara lain, akan berkembang sebagai konsekuensi dari pengetahuan kita tentang anak dan tentang apa yang diperlukan agar orang dewasa dapat mengembangkan kualitas hidup yang pantas. Alam dan iklim, politik dan ekonomi global serta kebudayaan global akan juga berpengaruh pada perkembangan total anak. Secara umum kita dapat mengatakan bahwa anak yang tumbuh dalam lingkungan alam dan iklim yang sangat berbeda akan mengembangkan perilaku dengan kualitas yang berbeda pula. Orang tua dan guru menghadapi tantangan besar jika mereka percaya untuk Memberi kesempatan kepada anak untuk berkembang sebagai seorang yang unik, seseorang dengan haknya sendiri, bukan sebagai citra orang dewasa. Di samping itu anak juga harus berkembang sebagai orang yang penuh pengertian dan sensitif terhadap orang lain. Ini akan menuntut rasa empati, kreatifitas dan fleksibilitas yang tinggi dari orang tua dan guru.

\section{Ilustrasi 2: Sebuah Pendekatan Holistik}

Kebudayaan global selama berabad-abad fisik sosial emosi intelektual iklim alam politik dan ekonomi global Lingkungan dekat Lingkungan jauh fungsi fisik (motorik dan indera) - fungsi sosial - fungsi emosional - fungsi intelektual

\section{Kreatifitas}


Apakah yang dimaksud dengan kreatifitas itu? Dapatkah orang mengembangkan kreatifitas? Banyak penelitian telah dilakukan mengenai konsep ini dan banyak jawaban yang diperoleh, tergantung pada latar belakang profesional penelitinya. Penjelasan tentang konsep ini tergantung pada apakah penelitinya mempunyai latar belakang ilmu fisika, ilmu sosial atau seni rupa. Banyak ahli yang telah mendefinisikan kreatifitas, dan semua definisinya berbeda, sekurang-kurangnya dalam aspek-aspek tertentu. Saya masih menyukai definisi yang dikemukakan oleh peneliti Norwegia Gunvor Rand (19xx) meskipun sudah bertahuntahun berlalu sejak konsepnya itu pertama kali disajikan. Dia telah merangkum hasil pencariannya atas konsep kreatifitas itu sebagai berikut:

Kreatifitas adalah proses di mana seorang individu, sebagai hasil dari kemampuan dan kesempatan pribadinya serta dalam interaksinya dengan lingkungannya, akan mencari produk baru dan/atau original yang memadai untuk situasi yang bersangkutan produk ini dapat bersifat konkret ataupun abstrak (Rand 1981:6). Penting untuk disadari bahwa kreatifitas adalah sebuah proses. Ada dua jenis utama kreatifitas: kreatifitas intuitif dan kreatifitas analitik. Kreatifitas intuitif adalah jenis kreatifitas yang terjadi secara spontan melalui improvisasi dan tanpa prameditasi. Ini yang terjadi bila orang spontan berbuat sesuatu, misalnya menari, bernyanyi atau memainkan alat musik, atau apa pun yang tiba-tiba terpikir olehnya. Kreatifitas analitik adalah apa yang kita gunakan, bila kita merencanakan, mengulang dan merekonstruksi kreasi kita dalam kaitannya dengan tujuan yang telah kita tetapkan.

\section{Kreatifitas dan struktur}

Selama bertahun-tahun telah berkembang mitos di negara-negara barat bahwa kreatifitas hampir sama artinya dengan kebebasan tanpa batas atau tanpa struktur sama sekali. Dengan menoleh ke belakang, kita akan dapat mengerti cara pikir seperti ini karena pengajaran seni rupa yang terlalu terstruktur dan sangat berorientasi pada keterampilan. Di masa lalu, kegiatan budaya juga terlalu terstruktur. Dalam kenyataannya kita telah mengalami bahwa sementara struktur yang berlebihan akan mencekik kreatifitas, sedangkan tidak adanya struktur dapat melumpuhkan kreatifitas. Dengan kata lain, agar kreatifitas muncul, kita memerlukan sebuah kerangka yang akan memungkinkan kreativitas berkembang.

Struktur yang saya maksudkan di sini dapat berkaitan dengan isi (topik, cerita, peristiwa, dll), unsur-unsur struktur seperti pilihan ritme, durasi, kualitas gerakan, bentuk dan/atau warna. Dengan mendefinisikan unsur-unsur seperti ini, dan mengaitkan improvisasi dan eksperimentasi dengan unsur-unsur tersebut atau mencobakan selangkah demi selangkah berbagai kombinasi unsur, bagi banyak orang dapat memberikan struktur yang diperlukan agar daya 
kreatifnya itu dapat dikeluarkan. Di pihak lain, kita harus berhati-hati agar tidak terlalu banyak melakukan pembatasan sehingga akan menghambat kreativitas.

\section{Kreatifitas dan lingkungan}

Kutipan dari Gunvor Rand di atas menunjukkan satu isu penting. Dia memberikan pengertian bahwa kreatifitas bukan hanya suatu anugrah yang dimiliki sedikit orang yang memang sangat berbakat. Ini berarti bahwa kreatifitas dapat dikembangkan oleh setiap orang, tanpa memandang kemampuan atau tingkat perkembangannya, jika diberi kesempatan oleh lingkungannya. Dia juga mengemukakan bahwa kreatifitas dapat dipandang sebagai proses berkesinambungan yang terkait dengan titik awal masingmasing orang. Namun kita melihat ada beberapa keterbatasan pada anak yang lahir butatuli. Kita tidak tahu apakah keterbatasan ini terletak pada diri anak atau pada pengasuhnya yang tidak dapat menemukan "pintu" bagi kreatifitas anak itu.

\section{Kreatifitas dan kehidupan sehari-hari}

Kreatifitas juga harus dipandang sebagai kemampuan untuk mengatasi tantangan dan memecahkan masalah, baik yang bersifat konkret dan praktis maupun abstrak dan filosofis. Penting untuk dapat melihat permasalahan dalam arti yang seluas-luasnya dan dari sudut pandang orang yang bersangkutan. Anak mungkin menggunakan seluruh energi dan kreatifitasnya untuk menghindari suatu kegiatan atau situasi yang menurut keyakinan orang tua atau guru baik dan menyenangkan bagi anak. Atau anak mungkin menggunakan energinya untuk menghindari hukuman. Dengan kata lain, anak dapat menggunakan energi kreatifnya untuk menghindari apa yang menurut pemikiran orang tua dan/atau guru merupakan hal yang terbaik bagi anak. Siapakah yang benar, anak atau orang tua/guru?

Bila solusi sebuah masalah (yang dapat dipandang sebagai "produk") itu "memadai untuk situasi yang bersangkutan" dan "original" bagi individu itu, hasilnya akan merupakan kreatifitas. Ini berarti bahwa tindakan yang sama yang dapat merupakan hasil dari proses kreatif seseorang mungkin bukan sebuah ungkapan kreatifitas bila dilakukan oleh individu lain. Kreatifitas dapat dimanifestasikan dalam bentuk yang konkrit atau abstrak, artinya produknya dapat berupa tindakan atau benda konkrit atau ungkapan pikiran dan perasaan. Kegiatan budaya atau juga disebut seni memberi kesempatan yang baik bagi anak (dan orang dewasa) untuk mengembangkan kreatifitasnya. Akan tetapi, menggunakan tanah liat atau krayon, alat musik atau gerakan tubuh itu belum tentu selalu mengembangkan kreatifitas. Yang penting adalah bagaimana kegiatan ini diterapkan, atau pendekatan dan metode apa yang dipergunakan dalam aktifitas ini sebagai alat untuk mengembangkan dan meningkatkan kreatifitas. Akan tetapi, metoda saja tidaklah cukup. Sensitifitas pengasuh atau guru terhadap ekspresi anak, perubahan suasana hati serta bakat untuk berinteraksi 
dan berkomunikasi merupakan dasar untuk membantu anak mengembangkan kreatifitasnya.

\section{Interaksi dan komunikasi}

Bagi semua anak, tanpa memandang tingkat perkembangannya dan jenis atau derajat kecacatannya, interaksi dan komunikasi merupakan fondasi penting untuk belajar dan berkembang. Perkembangan tidak terjadi secara vakum. Perkembangan terjadi secara simultan dalam semua bidang perkembangan, dan bidang-bidang ini saling terkait dan saling mempengaruhi. Pengasuh (dan guru) yang sensitif dan responsif dan berempati sangat dibutuhkan. Jika interaksi dan komunikasi tidak terjalin dan berkembang secara alami selama awal masa kanakkanak, kegiatan budaya dapat merupakan alat yang baik untuk itu. Konsep interaksi dan komunikasi sering dipergunakan tetapi mungkin diartikan secara berbeda-beda. Pada poin ini saya ingin menyajikan kedua konsep ini menurut pemahaman saya. Pemahaman ini telah berkembang sebagai hasil pengalaman saya bekerja dengan anak-anak yang menyandang kecacatan ganda di mana kurangnya atau buruknya interaksi dan komunikasi merupakan dua hambatan utama bagi mereka untuk belajar dan berkembang. Bekerja dengan anak-anak ini juga telah membuat saya sadar akan perlunya membedakan antara kedua konsep tersebut.

\section{Interaksi}

Interaksi adalah perhatian timbal balik antara dua orang (atau lebih) terhadap satu dengan lainnya atau terhadap suatu obyek atau orang ketiga. Mitra-mitra dalam interaksi ini memfokuskan perhatiannya pada sasaran yang sama (satu sama lainnya atau orang ketiga atau suatu obyek tertentu). Perhatian timbal balik ini sering kali direspon dengan isyarat, ujaran atau tindakan. Gerak isyarat dan ujaran ini setelah beberapa lama akan berkembang menjadi suatu dialog, 'percakapan', permainan bergiliran atau pertukaran antara "berbicara" dan mendengarkan. Ini dapat pula digambarkan sebagai inisiatif yang diambil dan reaksi yang diberikan oleh masing-masing mitra. Ini akan berkembang menjadi saling pengertian dan akhirnya ikatan kasih sayang. Pengalaman aksi dan reaksi ini akan mengembangkan kompentensi untuk memberikan perhatian, yang mencakup kemampuan untuk mengamati dan mendengarkan, dan merespon. Pengalaman-pengalaman ini lambat laun akan berkembang menjadi empati. (Empati adalah kemampuan untuk menempatkan diri pada situasi atau perasaan atau hakikat pemahaman orang lain).

\section{Komunikasi}

Komunikasi artinya pertama-tama adalah berbagi. Kita berbagi dan saling bertukar minat, perasaan, pikiran, pendapat atau informasi dengan media rangkaian kode-kode, yang terbentuk sebagai sinyal dan simbol-simbol, yang dapat 
dimengerti dan dipergunakan oleh semua mitra komunikasi itu. Akan tetapi, kode-kode saja tidak cukup untuk mengembangkan komunikasi. Komunikasi adalah proses yang kompleks di dalam dan di antara dua mitra (atau lebih). Beberapa langkah yang terlibat dibangun selama proses interaksi - berbagai kemampuan seperti kemampuan untuk memberikan perhatian, menatap dan/atau mendengarkan, termotivasi dan mampu menafsirkan apa yang difahami, dan termotivasi untuk merespon. Kemampuan-kemampuan ini mulai berkembang selama proses-proses interaksi dan sebelum kode-kode disepakati bersama. Perkembangan komunikasi akan didorong oleh kebutuhan untuk berkomunikasi.

Kebutuhan ini berkembang ketika bayi sadar bahwa inisiatifnya dapat membuat perubahan di dalam lingkungannya. Dengan kata lain, bayi secara bertahap sadar bahwa dia dapat mempengaruhi lingkungannya dan dapat memenuhi keinginannya. Jika proses interaksi dan komunikasi belum dapat berlangsung, akan sangat baik bila ada alat untuk membantunya. Tari dan musik, gambar dan model serta bentuk-bentuk kegiatan budaya lainnya dapat menjadi alat yang efektif untuk membantu perkembangan interaksi dan komunikasi. Dalam kenyataan hidup, interaksi dan komunikasi saling terkait dan saling melengkapi. Kualitas interaksi dan komunikasi yang tinggi ditandai oleh: sensitivitas, perhatian, reaktivitas, spontanitas, toleransi, kemurahan hati, fleksibilitas, kreatifitas dan empati.

Di dalam lingkungan sosial dan fisik yang cukup memuaskan, interaksi dan komunikasi biasanya akan terjalin dan terus-menerus dikembangkan melalui kegiatan-kegiatan yang alami. Akan tetapi, jika kondisi-kondisi seperti kecacatan, kesulitan emosional yang ekstrim serta kondisi lingkungan yang ekstrim seperti kelaparan, perang, pelecehan seksual dan kriminalitas lainnya terjadi, proses interaksi dan komunikasi itu mungkin tidak dapat terbina dan/atau dikembangkan lebih lanjut. Kondisi-kondisi yang disebutkan di atas bahkan dapat mengakibatkan anak-anak dan orang dewasa kehilangan kemampuan untuk berinteraksi dan berkomunikasi. Jika pengasuh dan/atau guru ingin membantu anak agar membangun, membangun kembali dan mengembangkan interaksi dan komunikasi, mereka harus sensitif, penuh perhatian, reaktif, spontan, toleran, murah hati, fleksibel, kreatif dan empatik: mereka perlu terlibat. Perkembangan interaksi dan komunikasi merupakan dasar untuk belajar dan berkembang, dan khususnya sangat penting bila kita menginginkan anak mengembangkan atau memulihkan rasa harga diri.

\section{Peranan kegiatan budaya}

\section{Peranan kegiatan budaya dalam mempromosikan:}

1. Pertumbuhan fisik, sosial, emosional dan kognitif individu sebagai anggota unit sosialnya (keluarga, kelas, masyarakat) 
2. - Pertumbuhan kelompok secara keseluruhan (sebagai hasil dari keragaman individu anggotanya).

Kegiatan budaya yang dibahas di sini merupakan alat penting yang dapat membantu kita untuk menolong anak dan orang dewasa untuk meraih pengalaman dan kompetensi sosial dan emosionalnya - suatu kompetensi yang sering terabaikan oleh pendidikan formal. Kompetensi sosial dan emosional tidak hanya penting untuk kesejahteraan anak tetapi kadang-kadang mencegah dan mengurangi kegagalan dan karenanya mencegah perasaan tidak berharga ketika anak tidak berhasil dalam melakukan tugas tertentu atau misalnya memahami semua yang diajarkan di kelas. (lihat juga Rye, 2001). Namun, bila kegiatan budaya diajarkan sebagai mata pelajaran keterampilan yang diwajibkan oleh kurikulum, bukan atas dasar minat individu siswa, kegiatan budaya juga dapat melahirkan kebosanan serta perasaan gagal.

Penting untuk tidak hanya membahas kegiatan budaya dari sudut pandang para partisipan tetapi juga dari sudut pandang pengamat, penonton, pendengar atau pemirsa. Pada tahun 70-an dan 80-an, ketika kegiatan budaya menjadi penting sebagai alat pendidikan, kita sering menekankan bahwa hanya keikutsertaan dalam kegiatan tersebutlah yang bermanfaat, misalnya dengan bernyanyi, menari, bermain peran dsb., yang dipandang berharga. Menjadi penonton, bagian dari pemirsa atau hadirin dianggap sebagai sebuah aksi hiburan yang memberikan tidak lebih dari sekedar kesenangan yang membuat pasif. Segera kita temukan bahwa kita harus juga aktif ketika menonton atau mendengarkan, dan bahwa ini tidak sama dengan "beristirahat". Sebaliknya, mendengarkan dan menonton dapat menjadi penting untuk pengayaan pengalaman dan dapat meningkatkan aktivitas dan kreatifitas orang. Menonton dan mendengarkan dapat meningkatkan kemampuan untuk mengamati dan menganalisis.

Akan tetapi, kita harus belajar dan berlatih untuk dapat menjadi penonton dan pendengar aktif dan analitik. Memberi feedback yang positif dan kritis dapat bermanfaat bagi kedua belah pihak. Keragaman akan dimanifestasikan juga di sini, ada orang yang senang mendengarkan musik tetapi tidak suka bernyanyi atau memainkan alat musik, ada pula yang senang bercerita tetapi tidak suka mendengarkan cerita. Ada orang yang ingin menari tetapi tidak dapat karena menyandang kecacatan fisik, ada pula yang senang menari tetapi tidak dapat mendengar. Ada orang yang hanya senang mendengarkan dan menonton karena tuntutan mereka akan kualitas tidak terpenuhi bila turut sebagai peserta.

\section{Guru dan kegiatan budaya}

Jika kita sungguh-sungguh ingin menggunakan kegiatan budaya sebagai alat untuk pertumbuhan dan bukan hanya sebagai orientasi budaya atau aktivitas 
waktu luang atau rekreasi, kita harus menggunakan alat ini secara seksama dan dengan kesadaran. Oleh karena itu, guru dan pendidik guru, orang tua, artis dan amatir/sukarelawan harus diberikan penyuluhan tentang bagaimana dan mengapa kegiatan budaya itu sangat penting. Juga otoritas yang bertanggung jawab untuk membuat kurikulum dan mereka yang memberikan dana harus diberikan penyuluhan serupa. Penting untuk menyediakan cukup waktu dan pelatihan yang kompeten di lembaga pendidikan guru, sekolah dan taman kanak-kanak. Guru harus melibatkan dirinya ke dalam aktivitas tersebut dan mempunyai pengalaman pribadi sebelum mereka dapat benar-benar memahami dan mengerti bagaimana aktivitas ini "bekerja" dan bagaimana cara menerapkan aktivitas tersebut sebagai alat pendidikan (dan pendidikan kebutuhan khusus).

Guru harus dapat memahami bagaimana mereka dapat menggunakan kegiatan budaya sebagai media untuk membantu anak mengembangkan rasa harga diri dan untuk memperkaya pengalaman mereka dan cakupan belajarnya, dan guru juga harus mengerti bagaimana kegiatan-kegiatan ini dapat membantu perkembangan proses menuju inklusi. Tidak cukup bagi guru untuk hanya memperoleh pemahaman melalui partisipasi saja. Guru juga harus belajar untuk menganalisis hakikat kegiatan tersebut dan bagaimana kegiatan ini dapat berdampak pada siswanya. Oleh karena itu, guru dan para profesional lainnya yang bekerja dengan orang yang berada pada masa pertumbuhan harus diberi kesempatan untuk membuat dirinya memenuhi syarat untuk menggunakan dan menerapkan kegiatan budaya untuk mempromosikan pertumbuhan individu siswa dan untuk mempromosikan proses inklusi. Ini bukan hanya sebatas belajar keterampilan dan metode. Guru harus memahami melalui pengalamannya bagaimana kegiatan tersebut dapat berpengaruh dan memicu emosi/perasaan dan rasa harga diri serta kegembiraan karena aktif secara fisik, emosional, intelektual dan sosial.

\section{Kesimpulan}

Budaya dan pendidikan merupakan dua hal yang saling berhubungan. Karena dalam pendidikan terjadinya transmisi budaya. Menurut E.B.tylor budaya adalah totalitas yang komplek yang mencakup pengetahuan, kebudayaan, seni, hukum, moral, adapt dan apa saja kemampuan-kemampuan dan kebiasaankebiasaan yang diperoleh orang sebagai anggota masyarakat. Disamping itu Mergeret Mead, budaya adalah seluruh komplek pelaku traditional yang lebih dikembangkan oleh ras manusia yang secara berurutan dipelajari oleh masingmasing generasi.

Untuk memahami nilai kegiatan budaya sebagai alat pendidikan, kita harus memperjelas pemahaman konsep-konsep dasar seperti: Kreatifitas adalah proses di mana seorang individu, sebagai hasil dari kemampuan dan kesempatan pribadinya serta dalam interaksinya dengan lingkungannya, akan mencari produk baru dan/atau original yang memadai untuk situasi yang bersangkutan produk 
ini dapat bersifat konkret ataupun abstrak. Interaksi dan komunikasi, Interaksi adalah perhatian timbal balik antara dua orang (atau lebih) terhadap satu dengan lainnya atau terhadap suatu obyek atau orang ketiga. Mitra-mitra dalam interaksi ini memfokuskan perhatiannya pada sasaran yang sama (satu sama lainnya atau orang ketiga atau suatu obyek tertentu). Perhatian timbal balik ini sering kali direspon dengan isyarat, ujaran atau tindakan. Sedangkan Komunikasi artinya pertama-tama adalah berbagi. Kita berbagi dan saling bertukar minat, perasaan, pikiran, pendapat atau informasi dengan media rangkaian kode-kode, yang terbentuk sebagai sinyal dan simbol-simbol, yang dapat dimengerti dan dipergunakan oleh semua mitra komunikasi itu.

Oleh karena itu, guru dan pendidik guru, orang tua, artis dan amatir/sukarelawan harus diberikan penyuluhan tentang bagaimana dan mengapa kegiatan budaya itu sangat penting. Juga otoritas yang bertanggung jawab untuk membuat kurikulum dan mereka yang memberikan dana harus diberikan penyuluhan serupa. Penting untuk menyediakan cukup waktu dan pelatihan yang kompeten di lembaga pendidikan guru, sekolah dan taman kanak-kanak. Guru harus melibatkan dirinya ke dalam aktivitas tersebut dan mempunyai pengalaman pribadi sebelum mereka dapat benar-benar memahami dan mengerti bagaimana aktivitas ini "bekerja" dan bagaimana cara menerapkan aktivitas tersebut sebagai alat pendidikan (dan pendidikan kebutuhan khusus).

Guru harus dapat memahami bagaimana mereka dapat menggunakan kegiatan budaya sebagai media untuk membantu anak mengembangkan rasa harga diri dan untuk memperkaya pengalaman mereka dan cakupan belajarnya, dan guru juga harus mengerti bagaimana kegiatan-kegiatan ini dapat membantu perkembangan proses pendidikan. 


\section{Daftar Pustaka}

Carling, Finn, 1975. Skeapt I vart bilde (Created in Our Image). Gyldendal Norsk Forlag A/S.

Carling, Finn. 1976. I et rom $i$ et bus $i$ en have (In a Room in a House in a Garden).Gyldendal Norsk Forlag A/S

Carling, Finn. 1988. Gjensyn fra en fremtid (Meeting from a Future). Gyldendal Norsk Forlag A/S

Rand, Gunvor. 1981. Ulike teoretiske syn på kreativitet (Different Theoretical Views of Creativity). University of Oslo

Sætersdal, Barbro. 1979. Foreldrepoesi (Parents' Poetry). J.W. Cappelens Forlag

Ørjasæter. Tordis. 1976. Boka om Dag Tore (The Book about my Son Dag Tore).

J.W. Cappelens Forlag AS.

Purwanto N Galim. 1985. Ilmu Pendidikan Teoritis dan Praktis. PT. Remaja Rosdakarya Offset. Bandung. 
192 | ISLAMIC COUNSELING: Jurnal Bimbingan dan Konseling Islam, vol. 2, no. 2, 2018 